\title{
Influence of orthodontic treatment on root resorption: a systematic review
}

\author{
Influência do tratamento ortodôntico na reabsorção radicular: uma \\ revisão sistemática
}

\author{
Luiz Fernando Nogueira de Brito* \\ Tadeu Evandro Mendes ${ }^{* *}$ \\ Anderson Paulo Barbosa Lima** \\ Renata Rodrigues de Almeida Pedrin ${ }^{* * * *}$ \\ Catielma Nascimento Santos ${ }^{* * * *}$ \\ Luiz Renato Paranhos*
}

\begin{abstract}
Objective: To perform a systematic review relating the existence of root resorption during orthodontic treatment. Methods: The research was performed in two electronic databases (PubMed and OpenGrey). The OpenGrey database was used exclusively for searching the "grey literature", avoiding selection and publication bias. Eligibility criteria included full texts available online, but with no language restriction. Aiming to work with more current articles on the subject, a filter for the last ten years was applied. Articles that had no direct relation with the main outcome of this study were excluded, as well as clinical case reports and opinions, literature review articles, editorials, and letters to the editor. All eligible studies were assessed for risk of bias and individual quality, and all research steps were performed independently by two eligibility reviewers. Results: Initially, 77 articles were selected, but after the application of exclusion criteria, only 71 were included. Six articles were eligible for qualitative assessment. Overall, incisors are the teeth most affected by root resorption and there is a higher rate of root resorption in retraction mechanics. Conclusion: There is a relationship between root resorption and orthodontic treatment.
\end{abstract}

Keywords: Orthodontic appliances. Root resorption. Tooth movement.

\section{Introduction}

Orthodontic treatment is important for aesthetic and functional rehabilitation of the stomatognathic system $^{1}$. The mechanical forces promoted by orthodontic therapy may cause undesirable effects, such as apical root resorption. Genetic disposition and individual biological variability are its main causes ${ }^{2}$, and the most affected teeth are upper incisors and bicuspids ${ }^{3}$. Most resorptions are clinically insignificant; however if achieving a severe level, they threaten the longevity of the affected teeth ${ }^{4}$.

Several studies ${ }^{3-6}$ report a correlation between root resorption and orthodontic treatment time. The amount and type of mechanics used are also critical for the presence or absence of root resorption ${ }^{3}$. Root length is usually measured in order to assess resorption, using periapical radiographs taken with the parallelism technique, since they have a higher level of reliability ${ }^{4,5,7}$.

The assessment of incidence and severity of root resorption is essentially important for the stability and longevity of orthodontic treatment. By applying a more simplified orthodontic therapy, orthodontists reveal the concern to reduce the time of treatment and the effect of mechanical forces on teeth, thus preventing root resorption. In this aspect, this study aimed to analyze through a systematic review whether orthodontic treatment is a factor that influences root resorption.

DDS, Private Practice, Três Pontas, MG, Brazil.

DDS, MSc, Professor, National Higher Education and Post-Graduation Institute Padre Gervásio, Inapós, Varginha, MG, Brazil.

DDS, Master's student in Orthodontics, Health Sciences Center, Sagrado Coração University, Bauru, SP, Brazil.

DDS, MSc, PhD, Professor, Health Sciences Center, Sagrado Coração University, Bauru, SP, Brazil.

DDS, MSc, Dentist, Department of Dentistry, Federal University of Sergipe, Lagarto, SE, Brazil.

DDS, MSc, PhD, Professor, Department of Dentistry, Federal University of Sergipe, Lagarto, SE, Brazil. 


\section{Methods}

\section{Research strategy for identification of studies and eligibility criteria}

Studies reporting the incidence of apical root resorption during orthodontic treatment and assessed by periapical and/or panoramic radiographs were selected. The point of the research was based on the PICO strategy. Eligibility and exclusion criteria are explained in Table 1.

Table 1 - Description of search strategy used in the research

\begin{tabular}{|c|c|}
\hline \multicolumn{2}{|l|}{ Search Strategy } \\
\hline \multicolumn{2}{|c|}{ Guiding Question: Does orthodontic treatment influence root resorption? } \\
\hline Components of the PICO Strategy & Description \\
\hline Population & Individuals treated by orthodontic therapy. \\
\hline Intervention & Therapy with orthodontic brackets. \\
\hline Comparison & Previous analysis of orthodontic treatment (baseline). \\
\hline Outcome & Presence or absence of tooth resorption, assessed by radiographic techniques. \\
\hline Electronic Databases & PubMed and OpenGrey \\
\hline \multicolumn{2}{|l|}{ Eligibility Criteria } \\
\hline Inclusion & Full texts available online, from the last 10 years. \\
\hline Exclusion & $\begin{array}{l}\text { Literature review studies, opinions, case reports, editorial and/or letter to } \\
\text { the editor. Studies that did not use radiographs (panoramic or periapical) as } \\
\text { assessment method. Studies performed on non-vital teeth. }\end{array}$ \\
\hline
\end{tabular}

Source: authors' elaboration.

It is a systematic literature review performed in the electronic databases PubMed and OpenGrey. The OpenGrey database was used to search the "grey literature" in order to avoid potential selection bias. The following descriptors were selected with MeSH: "Orthodontic Appliances", "Root Resorption", and "Tooth Movement." The Boolean operators AND and OR were applied to make the combinations.
Titles and abstracts of the identified studies were selected by two eligibility reviewers (L.F.N.B. and A.P.B.L.) working independently. Reviewers were not blinded to the names of authors and journals. The research was performed on December 13, 2014. Table 2 shows the search strategy used.

Table 2 - Strategies for database search

\begin{tabular}{|c|c|c|}
\hline Database & Search Strategy & Total \\
\hline \multirow{3}{*}{$\begin{array}{l}\text { PubMed } \\
\text { www.ncbi.nlm.nih.gov/pubmed/ }\end{array}$} & $\begin{array}{l}\text { (("orthodontic appliances"[MeSH Terms] OR ("orthodontic"[All Fields] AND } \\
\text { "appliances"[All Fields]) OR "orthodontic appliances"[All Fields]) AND ("root } \\
\text { resorption"[MeSH Terms] OR ("root"[All Fields] AND "resorption"[All Fields]) } \\
\text { OR "root resorption"[All Fields])) }\end{array}$ & 30 \\
\hline & $\begin{array}{l}\text { (("root resorption"[MeSH Terms] OR ("root"[All Fields] AND "resorption"[All } \\
\text { Fields]) OR "root resorption"[All Fields]) AND ("tooth movement"[MeSH Terms] } \\
\text { OR ("tooth"[All Fields] AND "movement"[All Fields]) OR "tooth movement"[All } \\
\text { Fields])) }\end{array}$ & 33 \\
\hline & $\begin{array}{l}\text { (("orthodontic appliances"[MeSH Terms] OR ("orthodontic"[All Fields] AND } \\
\text { "appliances"[All Fields]) OR "orthodontic appliances"[All Fields]) AND ("tooth } \\
\text { movement"[MeSH Terms] OR ("tooth"[All Fields] AND "movement"[All Fields]) } \\
\text { OR "tooth movement"[All Fields]) AND ("root resorption"[MeSH Terms] OR } \\
\text { ("root"[All Fields] AND "resorption"[All Fields]) OR "root resorption"[All Fields])) }\end{array}$ & 13 \\
\hline \multirow{3}{*}{$\begin{array}{l}\text { OpenGrey } \\
\text { http://www.opengrey.eu/ }\end{array}$} & "Orthodontic appliances" AND "root resorption" AND "humans" & 0 \\
\hline & "tooth movement" AND "humans" & 1 \\
\hline & Total & 77 \\
\hline
\end{tabular}


Titles and abstracts were systematically assessed. Studies rejected in this stage or subsequent stages were recorded in the exclusion table. When studies that were preliminarily included presented insufficient data in the title and abstract for making a clear decision, their full texts were obtained and assessed to determine whether they included all eligibility criteria. If there were questions about study data, the authors were contacted by e-mail for clarification.

\section{Individual quality of the studies}

The full texts of all eligible studies were assessed by methodological quality, through the checklist based on 8 criteria, adapted by Cericato et al. ${ }^{8}$ (2015): 1) Adequate study design scores 3 points; 2) Adequate presentation of the objectives scores 1 point; 3) Adequate sample size scores 1 point; 4) Adequate description of the sample selection process and sample loss scores 1 point; 5) Method used to analyze error scores 1 point; 6) Valid statistical method with declared value of $p$ scores 1 point; 7) Clear and objective presentation of the results scores 1 point; 8) Demographic characteristics of the cited studied population score 1 point. The assessment score could range from 0 to 10 . The studies were classified as low (score 0-4), moderate (score 5-7), or high (score 8-10) by methodological quality. The studies assessed as low quality (score 0 to 4) were considered methodologically poor and discarded. This entire research stage was analyzed by two eligibility reviewers (L.F.N.B. and A.P.B.L.) In case of disagreement, a third examiner (L.R.P.) was consulted. At this moment, reviewers were blinded to the authors and journals, avoiding any selection bias and conflicts of interest.

\section{Data extraction and analysis}

After screening, the full texts of selected articles were re-analyzed using a standardized data extraction sheet, in which authorship, publication year, sample qualification, age, objectives, results, and outcome of the studies were verified.

The process of data synthesis was performed through a descriptive analysis of the studies selected after the previous stage, and the final product of the analysis was presented in narration/ dissertation form.

\section{Results}

\section{Research strategy and individual quality of the studies}

The initial search resulted in a sample of 77 records in PubMed and OpenGrey databases. The main reasons for exclusion were studies not directly related to the primary outcome of the present study $(n=56)$, clinical case reports $(n=1)$, literature reviews $(\mathrm{n}=12)$, and editorials and/or letter to the editor $(n=2)$. Thus, the sample included a number of six articles, as shown in Figure 1.

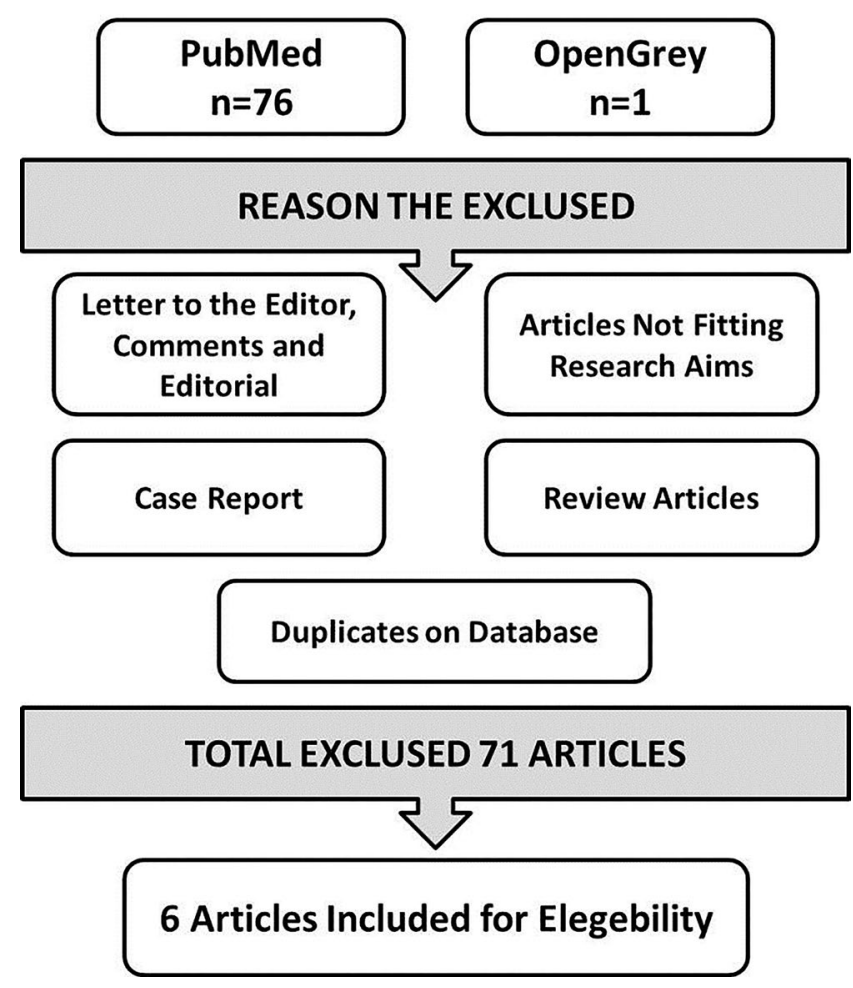

Figure 1 - Flow chart of literature search and selection criteria

Source: authors' elaboration.

In assessing the quality of studies, performed according to the aforementioned criteria, no article failed to be considered methodologically as "low quality" (0-4 score). It is worth mentioning the following important characteristic that was evident in the eligible studies: from the six selected articles, only one ${ }^{7}$ commented on ethical criteria involved in the research.

\section{Included studies and intervention effects}

Table 3 explains the studies selected. The studies by Apajalahti \& Peltola ${ }^{3}$ (2007) and Nigul \& Jagomagi $^{5}$ (2006) analyzed root resorption through panoramic radiograph, Mohandesan et al. ${ }^{6}(2007)$, Loenen et al. ${ }^{7}$ (2007), and Ramanathan \& Hofman ${ }^{9}$ (2009) assessed root resorption through periapical radiographs, and Jiang et al. ${ }^{4}$ (2010) used both radiographic techniques to assess root resorption. 
Table 3 - Main characteristics of eligible studies

\begin{tabular}{|c|c|c|c|c|c|}
\hline $\begin{array}{l}\text { Authorship and } \\
\text { publication year }\end{array}$ & $\begin{array}{c}\text { Sample } \\
\text { qualification }\end{array}$ & $\begin{array}{c}\text { Age } \\
\text { (Years) }\end{array}$ & Objectives & Results & Outcome \\
\hline $\begin{array}{l}\text { Nigul \& Jagomagi }{ }^{5} \\
(2006) \\
\text { Estonia* }\end{array}$ & $\begin{array}{l}75 \text { participants } \\
23 \text { 人 } \\
52 \text { ㅇ }\end{array}$ & $\begin{array}{l}46 \text { children } \\
(<16 \text { years old }) \\
29 \text { adults }\end{array}$ & $\begin{array}{l}\text { To determine the length } \\
\text { of apical root resorption } \\
\text { at the end of orthodon- } \\
\text { tic treatment and try to } \\
\text { identify the potential } \\
\text { factors for predicting the } \\
\text { incidence of resorption } \\
\text { before the beginning of } \\
\text { treatment. }\end{array}$ & $\begin{array}{l}\text { The resorption of maxillary incisors } \\
\text { is in average } 1.5 \mathrm{~mm} \text {. Severe root } \\
\text { resorption was observed in } 2.6 \% \text { of } \\
\text { teeth and in teeth with abnormal root } \\
\text { contour. No significant differences } \\
\text { were assessed between men and } \\
\text { women, and between children and } \\
\text { adults. However, treatment therapy } \\
\text { and time showed statistically signifi- } \\
\text { cant difference }(p>0.05) \text {. }\end{array}$ & $\begin{array}{l}\text { Statistically significant dif- } \\
\text { ferences were measured } \\
\text { and proven. The main in- } \\
\text { dicators for pre-treatment } \\
\text { root resorption were deter- } \\
\text { mined, namely, abnormal } \\
\text { root contour, treatment time } \\
\text { with the use of rectangular } \\
\text { strings, and use of accesso- } \\
\text { ries with metal slot. }\end{array}$ \\
\hline $\begin{array}{l}\text { Apajalahti \& } \\
\text { Peltola }^{3} \\
(2007) \\
\text { Finland* }\end{array}$ & 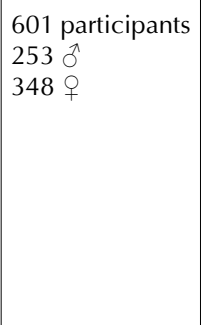 & 8-16 & $\begin{array}{l}\text { To compare the inci- } \\
\text { dence and severity of } \\
\text { root resorption in teeth } \\
\text { treated with different } \\
\text { orthodontic appliances, } \\
\text { assessing their effects } \\
\text { during treatment. }\end{array}$ & $\begin{array}{l}79 \text { men }(31 \%) \text { and } 120 \text { women } \\
(34 \%) \text { showed no significant root re- } \\
\text { sorption }(p<0.001) .56 \% \text { of the par- } \\
\text { ticipants presented level } 2 \text { of resorp- } \\
\text { tion in longer treatments ( } p<0.01) \text {. } \\
\text { The average time of treatment in pa- } \\
\text { tients with no significant resorption } \\
\text { was } 1.5 \text { years, while for those with } \\
\text { resorption level } 2 \text { the average time } \\
\text { was } 2.3 \text { years. }\end{array}$ & $\begin{array}{l}\text { The study shows that there } \\
\text { is significant correlation be- } \\
\text { tween the time of treatment } \\
\text { and the level of resorption } \\
\text { presented. A radiographic } \\
\text { control is advised at an } \\
\text { interval of six months to } \\
\text { measure the level of root } \\
\text { resorption. }\end{array}$ \\
\hline $\begin{array}{l}\text { Mohandesan } \\
\text { et al. }{ }^{6} \\
(2007) \\
\text { Iran* }\end{array}$ & $\begin{array}{l}40 \text { participants } \\
16 \hat{0} \\
24 \text { ㅇ }\end{array}$ & $12-22$ & $\begin{array}{l}\text { To measure the amount } \\
\text { of resorption and assess } \\
\text { its clinical significance } \\
\text { during a period of active } \\
\text { orthodontic treatment. }\end{array}$ & $\begin{array}{l}\text { For central incisors, the average of } \\
\text { root resorption in the first semes- } \\
\text { ter of an orthodontic treatment was } \\
0.77 \pm 0.42 \mathrm{~mm}, 4.5 \% \text { of initial root } \\
\text { length }(p<0.001) \text {. In twelve months, } \\
\text { the amount of resorption increased } \\
\text { to } 1.67 \pm 0.64,9.8 \% \text { of initial length } \\
(p<0.001) \text {. } \\
\text { For lateral incisors, the average root } \\
\text { resorption was } 0.88 \pm 0.51 \mathrm{~mm} \text {, } \\
5.6 \% \text { of initial root length }(p<0.001) \text {. } \\
\text { In twelve months, the amount of ab- } \\
\text { sorption increased to } 1.79 \pm 0.66 \text {, } \\
11.5 \% \text { of initial length }(p<0.001) \text {. }\end{array}$ & $\begin{array}{l}\text { Root resorption is a con- } \\
\text { cern in orthodontic treat- } \\
\text { ment. In this survey, max- } \\
\text { illary incisors showed a } \\
\text { significant rate of root re- } \\
\text { sorption, which considers } \\
\text { treatment time and therapy } \\
\text { used. } \\
\text { Standardized monitoring } \\
\text { radiographs at frequent in- } \\
\text { tervals could help in early } \\
\text { intervention to root resorp- } \\
\text { tion. }\end{array}$ \\
\hline $\begin{array}{l}\text { Loenen et al. } \\
\text { (2007) } \\
\text { Belgium* }\end{array}$ & $\begin{array}{l}31 \text { participants } \\
11 \text { o } \\
20 \text { 오 }\end{array}$ & $\begin{array}{l}13.6 \text { ( } \pm 3 \text { years } \\
\text { and } 3 \text { months) }\end{array}$ & $\begin{array}{l}\text { To investigate whether } \\
\text { the incidence of root } \\
\text { resorption is higher in } \\
\text { the torque stage, in the } \\
\text { Tip-Edge }{ }^{T M} \text { appliance } \\
\text { of central and lateral } \\
\text { incisors, during torquing } \\
\text { (third stage) than non- } \\
\text { torquing (first two stages) } \\
\text { of orthodontic treatment. }\end{array}$ & $\begin{array}{l}\text { Although } 48 \% \text { of central incisors in } \\
\text { the present study present root resorp- } \\
\text { tion at T2 (end of the alignment and } \\
\text { leveling stage), only } 33 \% \text { of affected } \\
\text { teeth tended to increase root resorp- } \\
\text { tion at T3 (end of treatment). } \\
\text { For lateral incisors, the rates were } \\
\text { slightly different, and } 62 \% \text { presented } \\
\text { root resorption at } 2 . \text { In addition, } \\
38 \% \text { of these incisors presented root } \\
\text { resorption at T3, Both were com- } \\
\text { pared to T1 (beginning of treatment) } \\
\text { ( } p<0.001 \text { ). }\end{array}$ & $\begin{array}{l}\text { The torque stage in the Tip- } \\
\text { Edge }^{\mathrm{TM}} \text { appliance is accom- } \\
\text { panied by the same amount } \\
\text { of apical root resorption in } \\
\text { maxillary incisors as other } \\
\text { tooth movements in the } \\
\text { orthodontic treatment. }\end{array}$ \\
\hline $\begin{array}{l}\text { Ramanathan \& } \\
\text { Hofman }^{9} \\
(2009) \\
\text { Czech Republic }\end{array}$ & $\begin{array}{l}49 \text { participants } \\
20 \hat{0} \\
29 \text { ㅇ }\end{array}$ & \pm 14.5 & $\begin{array}{l}\text { To compare the length of } \\
\text { root resorption of maxil- } \\
\text { lary incisors during dif- } \\
\text { ferent orthodontic move- } \\
\text { ments. }\end{array}$ & $\begin{array}{l}\text { Radiographs were taken after the } \\
\text { leveling stage in groups } 1 \text { and } 2 \text {, } \\
\text { and group } 3 \text { - beginning of treat- } \\
\text { ment (T1). The } p \text { values were } 0.056 \\
\text { (groups } 2 \text { and } 3 \text { ) and } 0.0925 \text { (groups } \\
3 \text { and } 1 \text { ). There was no significant } \\
\text { difference of root resorption intra } \\
\text { and inter-groups. }\end{array}$ & $\begin{array}{l}\text { Regardless of biomechanics } \\
\text { or technique used, apical } \\
\text { root resorption in maxillary } \\
\text { incisors has no statistically } \\
\text { significant difference, and } \\
\text { no correlation with age and } \\
\text { gender of the patient. }\end{array}$ \\
\hline $\begin{array}{l}\text { Jiang et al. }{ }^{4} \\
(2010) \\
\text { China* }\end{array}$ & $\begin{array}{l}96 \text { participants } \\
34 \text { ? } \\
62 \text { ㅇ }\end{array}$ & $9-34$ & $\begin{array}{l}\text { To assess root resorp- } \\
\text { tion before and after or- } \\
\text { thodontic treatment. }\end{array}$ & $\begin{array}{l}\text { The statistical analysis revealed no } \\
\text { significant difference between gen- } \\
\text { ders for resorption at } \mathrm{T} 1 \text { and } \mathrm{T} 2 \text { in- } \\
\text { tervals. However, in the extraction } \\
\text { therapy at } \mathrm{T} 2 \text {, the difference for the- } \\
\text { rapy with no extraction presented a } \\
\text { statistically significant difference ( } \mathrm{p} \\
=0.000, \mathrm{p}<0.01) \text {. Consequently, the } \\
\text { time of treatment with the extraction } \\
\text { therapy was longer, which showed a } \\
\text { statistically significant difference ( } \mathrm{p}= \\
0.036, \mathrm{p}<0.05) \text {. }\end{array}$ & $\begin{array}{l}\text { Age, extraction therapy, } \\
\text { and treatment time have } \\
\text { close relation regarding } \\
\text { apical root resorption in } \\
\text { orthodontic treatment. }\end{array}$ \\
\hline
\end{tabular}

${ }^{*}$ Country the study was performed. $\delta=$ Male gender. $q=$ Female gender.

Source: authors' elaboration. 
Some studies ${ }^{3,5}$ claim that treatment time directly influences level of resorption and therapy used. Upper incisors showed greater resorption $(60 \%)$, followed by lower incisors $(20 \%)^{3}$.

No level of influence of external factors, such as age, gender, dental position, and time of treatment was statistically significant on root resorption ${ }^{5}$.

Periapical and/or panoramic radiographs were used to predict and anticipate possible root resorption of higher intensity ${ }^{4,6,7,9}$. Ramanathan \& Hofman $^{9}$ (2009) radiographically assessed root resorption after fixed appliance bonding (T1) and after intrusion and retraction (T2), and found more root resorption in the intrusion and retraction stage when compared to other stages of the treatment.

External root resorption, measured in millimeters over a period of 12 months, confirmed to be greater in upper incisors $(11.1 \mathrm{~mm}$ for central incisor and $12.7 \mathrm{~mm}$ for lateral incisors) when the treatment plan required tooth extractions ${ }^{6}$.

The Tip-Edge ${ }^{\mathrm{TM}}$ appliance (Appliance TP Orthodontics, La Porte, Indiana, USA) at T1 (baseline) presented the length of $13 \mathrm{~mm}$ for central and lateral incisors, at T2 (after the alignment and leveling stage) of $12.1 \mathrm{~mm}$ for central and lateral incisors, and at T3 (after torque stage) of $11.6 \mathrm{~mm}$ for central incisors and $11.1 \mathrm{~mm}$ for lateral incisors ${ }^{7}$.

\section{Discussion}

Root resorption in permanent teeth is potentially a scar from orthodontic treatment. Opinions among researchers about the incidence and severity of root resorption assessed during orthodontic treatment are divergent. Root resorption appears to be multifactorial, combined with mechanical effects and a genetic disposition of the individual. Faced with different statements, this study became necessary to clarify whether orthodontic treatment influences dental resorption.

Nigul \& Jagomagi ${ }^{5}$ (2006) state that root shape is major for root resorption. It is characterized morphologically and radiographically by a root apex rounding; however, it may present itself in varying levels ${ }^{5}$. Most root resorptions are clinically irrelevant, but if severe, they may influence tooth longevity ${ }^{4}$

Panoramic and periapical radiographs were used by authors ${ }^{3-7,9}$ to assess root resorption and its relation to orthodontic treatment, although some authors ${ }^{4}$ state that teleradiography is the technique with the best location method to compare root length before and after treatment.

The use of panoramic radiographs to assess root resorption and shape presents a few negative points. The use of this technique may maximize the length of root loss by 20 percent $^{4}$. The study described by Apajalahti \& Peltola ${ }^{3}$ (2007) used the measure of root length, and pre- and post- treatment, instead of measuring absolute values of apical root loss. Incisor angulations may change during orthodontic treatment, which may interfere with the measurement of root length in the radiographic image; however, in the panoramic radiograph, buccolingual inclinations intervene in root length only by a limited range of $10 \mathrm{~mm}$, which when interpreted, causes a difference of only five percent $^{3}$.

In the study by Jiang et al. ${ }^{4}$ (2010), the authors state that there was no statistically significant difference in root resorption between men and women. Nigul \& Jagomagi ${ }^{5}$ (2006) found that men present more root resorption, but with no statistically significant differences. Adults had more root resorption than children, but the results were not statistically different ${ }^{5}$.

Intrusion and retraction, whether performed simultaneously or consecutively, do not affect root length ${ }^{9}$. The authors state that the most causal variable of root resorption in this movement would be the force applied, suggesting that $10 \mathrm{cN}$ per incisor would be ideal. They suggest these claims should be substantiated by further studies ${ }^{9}$.

Although torque is not the only causal aggravating factor to root resorption, it needs to be considered $^{7}$. The authors measured the root length of central and lateral incisors early in the treatment after the alignment and leveling stage, and finally, after the additional stage of torque applications. They concluded that central and lateral incisors had an average root length of $12.1 \mathrm{~mm}$ in the alignment and leveling stage. By the end of treatment, central incisors presented an average root length of 11.6 $\mathrm{mm}$ and the lateral ones presented an average length of $11.1 \mathrm{~mm}^{7}$.

Orthodontic treatment with dental extraction is favorable to root resorption and the pattern of extraction was a significant factor. Orthodontic therapy with four extractions of the first bicuspids presented more root resorptions than patients treated with no extractions ${ }^{5}$. In the study by Jiang et al. ${ }^{4}$ (2010), only anterior and mandibular teeth had a statistically significant correlation with root resorption and extraction.

Patients with longer treatment time presented a higher level of root resorption. The mechanics employed in tooth movement is also a determining factor $^{3}$. Potential for root resorption tends to vary among patients treated orthodontically, whereas it occurs in a varying level in teeth of the same patient. Individual biological factors, alveolar shape, bone density, vascularity, and tooth structure may explain these characteristics ${ }^{3}$.

Root shape directly influences the level of resorption. The resorption of small, torn, and pipette-shaped roots is almost twice than for other root shapes ${ }^{5}$. The authors found no association between root resorption and previous history of trauma ${ }^{5}$. Further studies with a larger sample and better definition of the study groups are required to increase the strength of this evidence. 


\section{Limitations}

A clear limitation of the study is the genetic disposition and individual biological variability of each patient treated orthodontically, considering it may or may not cause root resorption, regardless of the number of predisposing factors ${ }^{2,3}$. There may be bias in sample selection when determining an orthodontic therapy with less time (with no extraction $)^{4,5}$, since the level of root resorption will be reduced. Another limitation would be the uniformity of the analyzed teeth, in which some authors of this study ${ }^{5,6}$ state that incisors are more prone to root resorption. The therapy ${ }^{3}$ and force used in tooth movement is a variable to be considered ${ }^{9}$. The adequate force used for orthodontic movement without generating iatrogenic root resorption is still uncertain, and new studies should be performed ${ }^{9}$. Developing more uniform studies with similar therapy is required, as well as analyzing numerous brands and models of orthodontic appliances, along with various techniques described in the literature.

\section{Conclusion}

All studies showed that individuals who were subjected to orthodontic treatment are likely to present root resorption, thus, there is a relationship between root resorption and orthodontic treatment. However, the heterogeneity of the eligible studies was evident, and therefore this conclusion should be interpreted with caution.

\section{Resumo}

Objetivo: realizar uma revisão sistemática relacionando a existência da reabsorção radicular durante o tratamento ortodôntico. Metodologia: a pesquisa foi realizada em duas bases de dados eletrônicas (PubMed e OpenGrey). A base OpenGrey foi utilizada, exclusivamente, para captação da "literatura cinza", evitando viés de seleção e publicação. Como critérios de elegibilidade, foram utilizados os textos completos disponíveis on-line, sem restrição de idioma; propondo trabalhar com artigos mais atuais sobre o tema, foi aplicado o filtro para os últimos dez anos. Os artigos que não tinham relação direta com o principal resultado deste estudo foram excluídos, bem como os relatos de casos clínicos e opiniões, artigos de revisão da literatura, os editoriais e as cartas ao editor. Todos os estudos elegíveis foram avaliados quanto ao risco de viés e qualidade individual. Todas as fases da revisão foram realizadas por dois revisores de elegibilidade de forma independente. Resultados: inicialmente, 77 artigos foram indicados, mas, após a aplicação dos critérios de exclusão, apenas 71 foram selecionados. Assim, elegeram-se para avaliação qualitativa seis artigos. De maneira geral, os incisivos são os dentes mais acometidos pela reabsorção radicular, sendo que, em mecânicas de retração, o índice de reabsorção radicular é maior. Conclusão: existe relação entre a reabsorção radicular e o tratamento ortodôntico.

Palavras-chave: Aparelhos ortodônticos. Reabsorção da raiz. Movimentação dentária.

\section{References}

1. Limpanichkul W, Godfrey K, Srisuk N, Rattanayatikul C. Effects of low-level laser therapy on the rate of orthodontic tooth movement. Orthod Craniofac Res 2006; 9(4):38-43.

2. Weltman B, Vig KWL, Fiels HW, Shanker S, Kaizar EE. Root resorption associated with orthodontic tooth movement: A systematic review. Am J Orthod Dentofacial Orthop 2010; 137(9):462-76.

3. Apajalahti S, Peltola JS. Apical root resorption after orthodontic treatment - a retrospective study. Eur J Orthod 2007; 29(1):408-12.

4. Jiang R, McDonald JP, Fu M. Root resorption before and after orthodontic treatment: a clinical study of contributory factors. Eur J Orthod 2010; 32(1):693-7.

5. Nigul K, Jagomagi T. Factors related to apical root resorption of maxillary incisors in orthodontic patients. Stomatologija 2006; 8(3):76-9.

6. Mohandesan H, Ravanmehr H, Valaei N. A radiographic analysis of external apical root resorption of maxillary incisors during active orthodontic treatment. Eur J Orthod 2007; 29(2):134-9.

7. Loenen MV, Dermaut LR, Degrieck J, De Pauw GA. Apical root resorption of upper incisors during the torquing stage of the tip-edge technique. Eur J Orthod 2007; 29(1):583-8.

8. Cericato GO, Bittencourt MAV, Paranhos LR. Validity of the assessment method of skeletal maturation by cervical vertebrae: a systematic review and meta-analysis. Dentomaxillofac Radio 2015; 44(4):20.140.270.

9. Ramanathan C, Hofman Z. Root resorption during orthodontic tooth movements. Eur J Orthod 2009; 31(1):578-83.

\section{Correspondence address:}

Luiz Renato Paranhos

Al. Jordão de Oliveira, 996.

Residencial Vista do Atlântico, ap. 1.402

Bairro Atalaia

49037-330 Aracaju, Sergipe

Phone: (55) (79) 991161896

E-mail: paranhos.Irp@gmail.com

Recebido: 14/07/2016. Aceito: 22/09/2016. 